\title{
ANALISIS KETERAMPILAN PROSES SAINS MAHASISWA PADA PRAKTIKUM MENGGUNAKAN E-MODUL
}

\author{
Retno Wulan Dari dan Neng Ria Nasih \\ Universitas Jambi \\ e-mail:wulan21789@gmail.com
}

\begin{abstract}
Abstrak
Penelitian ini bertujuan untuk mengetahui tingkat keterampilan proses sains mahasiswa pada praktikum menggunakan e-modul. Pendekatan penelitian ini adalah pendekatan kuantitatif. Jumlah sampel pada penelitian ini ialah 40 mahasiswa. Teknik pengambilan sampel menggunakan total sampling. Instrumen yang digunakan pada penelitian ini ialah lembar observasi keterampilan proses sains yang sudah divalidasi. Data keterampilan proses sains yang diperoleh dianalisis menggunakan statistik deskriptif. Hasil penelitian menunjukkan Keterampilan Proses Sains Mahasiswa Pendidikan Fisika Universitas Jambi pada praktikum menggunakan e-modul.

Kata Kunci: E-Modul, Keterampilan Proses Sains, Pembiasan Pada Prisma

\section{Abstract}

This study aims to determine the level of science process skills of students on practicum using e-modules. The approach of the study was quantitative. The sample in this study was 40 students. The sampling technique used total sampling. The instrument used in this study was a validated scientific process skill observation sheet. The data on science process skills obtained were analyzed using descriptive statistics. The results showed that the Science Process Skills of Physics Education Students of Jambi University in practicum used e-modules.
\end{abstract}

Keywords: E-Module, Science Process Skills, Prism Refraction

\section{PENDAHULUAN}

Fisika merupakan pembelajaran dengan ilmu pengetahuan yang membahas sesuatu yang berada di alam (Darmaji, Astalini et al., 2019). Fisika adalah salah satu mata pelajaran yang membahas fenomena dan gejala nyata. Pembelajaran fisika yang berpacu pada konsep-konsep memerluan pemahaman yang tinggi (Putri, Maison, \& Darmaji, 2018). Fisika adalah cabang ilmu yang memiliki keunikan dan karakteristik (Maison, Syahrial, Syamsurizal, \& Tanti, 2012). Fisika dipandang sebagai suatu proses dan produk, sehingga strategi atau metode pembelajaran yang digunakan harus efektif dan efisien Astuti (2015). Fisika memainkan peran penting dalam menjelaskan berbagai fenomena yang terjadi di alam semesta (Maison, Astalini, Kurniawan, 2018). Astalini et al (2019), fisika telah menjadi salah satu mata pelajaran yang terkait dengan pendidikan sains. Pelajaran fisika berhubungan dengan kegiatan praktikum. 
Kegiatan praktikum akan membentuk keterampilan proses sains pada peserta didik, terutama praktikum mandiri seperti kegiatan praktikum berbasis proyek lebih efektif dari praktikum yang terbimbing (Nasir, 2019). Keterampilan proses sains adalah keterampilan yang perlu ditanamkan pada praktikkan, dan dimiliki oleh peserta didik (Wahyuni, Indrawati, Sudarti, \& Suana, 2017). Keterampilan proses sains adalah keterampilan berpikir yang digunakan untuk menciptakan pengetahuan, menyelesaikan masalah dan merumuskan hasil (Aydın, 2013). Keterampilan proses sains peserta didik dapat dilihat dari kegiatan praktikum yang mengarah pada konsep dalam pembelajaran dan penerapan ilmu pengetahuan (Karamustafaoğlu, 2011). Keterampilan proses sains adalah alat yang digunakan peserta didik untuk menyelidiki dunia di sekitar mereka dan untuk membangun konsep-konsep sains (Gultepe, 2016). Keterampilan proses sains adalah keterampilan yang melibatkan kognitif atau aspek intelektual, manual, sosial, mental dan fisik yang berfungsi sebagai alat yang diperlukan untuk pembelajaran yang efektif, pemecahan masalah, dan pengembangan individu dan kelompok (Nugraha, Utari, Saepuzaman, Solihat, \& Kirana, 2019).

Keterampilan proses sains terbagi menjadi dua kelompok yaitu keterampilan proses sains dasar dan terintegrasi (Hırça, 2012). Keterampilan proses sains dasar meliputi observasi, klaifikasi, mengukur, predikasi, komunikasi dan menyimpulkan (Ergul et al., 2011). Sedangkan keterampilan proses sains terintegrasi meliputi Identifikasi Variabel, Menyusun tabel data, Membuat grafik, Memperoleh dan memproses data, Mendeskripsikan hubungan antar variabel, Mengidentifikasi variabel secara operasional, Membuat hipotesis, Analisis percobaan, Merancang investigasi, dan Melakukan eksperimen (Dönmez \& Azizoğlu, 2010). Dari pengertian diatas menunjukkan bahwa dengan keterampilan proses, peserta didik berusaha menemukan dan mengembangkan kemampuan kognitif dan psikomotor.

Keterampilan Proses Sains peserta didik dapat diterapkan melalui Teknologi Informasi komunikasi (TIK) yang berpengaruh sangat besar dalam usaha pengembangan keterampilan peserta didik dalam proses pembelajaran. Astalini, Darmaji, Kurniawan, Anwar, \& Kurniawan (2019), menyatakan bahwa "Education in the present very much requires the use of technology to improve the competence of increasing human resources". Seiring perkembangan TIK terutama internet maka peluang penerapan e-learning sangat besar. Asrial, Syahrial, Kurniawan, Perdana, \& Nugroho, (2019), menyatakan bahwa "By using e-learning, students will become more motivated in learning ". Menurut Suarsana \& Mahayukti (2013), penerapan e-learning tefokus pada menuntut mahasiswa mandiri dalam belajar, maka pengembangan perangkat pembelajaran yang diprioritaskan adalah e-modul (elektronik-modul). E-modul merupakan suatu modul berbasis TIK, E-modul memiliki kelebihan tersendiri dibandingkan dengan modul cetak e-modul memiliki sifat yang 
interaktif memudahkan, bisa menampilkan/memuat gambar, audio, video dan animasi serta dilengkapi tes/kuis formatif yang bisa menjadi umpan balik dalam membantu pengguna. Hal ini sesuai dengan pendapat Cahyani \& Setyawati (2016), menyatakan bahwa cara yang bisa dilakukan untuk melatih keterampilan proses sains peserta didik dengan cara membiasakan mereka melakukan pemecahan sebagai suatu pendekatan pembelajaran fisika.

Penelitian ini tentang keterampilan proses sains dasar dan terintegrasi pada indikator observasi, mengukur, menganalisis investigasi, dan melakukan eksperimen pembiasan pada prisma. Kunlestiowati, Yuningsih, Martono, \& Politeknik (2016), menyatakan bahwa pembiasan cahaya dapat terjadi pada prisma, antara lain diterapkan pada prinsip kerja dari suatu alat yaitu spektrometer berupa alat optik yang digunakan untuk mengamati dan mengukur sudut deviasi cahaya datang karena pembiasan dan dispersi. Menurut Willingham (2008),"The development of such scientific concepts will support subsequent capabilities such as creativity, critical thinking skills, and greater accuracy or abilities, where such abilities are often used in everyday life". Darmaji, Dwi Agus Kurniawan, Hanaiyah Parasdila (2018) menyatakan bahwa "the development of such scientific concepts will support subsequent capabilities such as creativity, critical thinking skills, and greater accuracy or abilities, where such abilities are often used in everyday life".

Praktikum fisika dasar yang menggunakan e-modul sangat membantu tenaga pendidik dalam menciptakan keterampilan proses sains peserta didik, e-modul dikembangkan untuk mengembangkan kemampuan individual peserta didik dalam menyelidiki objek, gejala, dan persoalan-persoalan dimana pendidik bertindak sebagai fasilitator dan komentator terhadap permasalahan yang dihadapi peserta didik dalam menentukan prosedur kerja, analisis data, dan pengambilan kesimpulan. Karena didalam e-modul yang dikembangkan ada berbagai kegiatan sains yag dapat dikerjakan peserta didik secara individual. Melalui penelitian ini diharapkan diperoleh e-modul praktikum yang efektif dalam meningkatkan keterampilan sains.

\section{METODE}

Pendekatan yang digunakan dalam penelitian ini adalah pendekatan kuantitatif. Sampel penelitian ialah seluruh mahasiswa pendidikan fisika angkatan 2018 yang berjumlah 40 orang. Penelitian ini menggunakan teknik pengambilan sampel, yaitu total sampling (Dari \& Nasih, 2019; Putri et al., 2018). Instrumen yang digunakan pada penelitian ini adalah lembar observasi keterampilan proses sains yang sudah divalidasi. Observasi ini dibantu oleh observer yang berjumlah 25 orang. Keterampilan proses sains dalam pengamatan dibagi menjadi dua kategori yaitu keterampilan proses sains dasar dan 
keterampilan proses sains terintegrasi. Keterampilan proses dasar yang diamati yaitu pada indikator observasi, mengukur. Keterampilan proses terintegrasi yang diamati yaitu , menganalisis investigasi, dan melakukan eksperimen (Karamustafaoğlu, 2011). Data keterampilan proses sains yang diperoleh dianalisis menggunakan statistik deskriptif. Untuk menentukan penguasaan keterampilan proses sains mahasiswa terdiri dari 4 kriteria seperti pada Tabel 1.

Tabel 1. Interval Penguasaan Keterampilan Proses Sains Dasar Melakukan Observasi Dan Mengukur

\begin{tabular}{|c|c|c|c|c|c|c|}
\hline No & & Interval & kategori & & Interval & Kategori \\
\hline 1 & & $5.00-8.75$ & $\begin{array}{l}\text { Sangat } \\
\text { Tidak Baik }\end{array}$ & & $1.00-1.75$ & Sangat Tidak Baik \\
\hline 2 & & $8.76-12.50$ & Tidak Baik & & $1.76-2.50$ & Tidak Baik \\
\hline 3 & Observasi & $\begin{array}{l}12.51- \\
16.25\end{array}$ & Baik & Mengukur & $2.51-3.25$ & Baik \\
\hline 4 & & $\begin{array}{l}16.26- \\
20.00\end{array}$ & $\begin{array}{l}\text { Sangat } \\
\text { Baik }\end{array}$ & & $3.26-4.00$ & Sangat Baik \\
\hline
\end{tabular}

Tabel 2. Interval Penguasaan Keterampilan Proses Sains Terpadu Menganalisis Percobaan dan Melakukan Percobaan

\begin{tabular}{|c|c|c|c|c|c|c|}
\hline No & & Interval & Kategori & & Interval & Kategori \\
\hline 1 & & $\begin{array}{l}4.00- \\
7.00\end{array}$ & $\begin{array}{l}\text { Sangat Tidak } \\
\text { Baik }\end{array}$ & & $\begin{array}{l}9.00- \\
14.75\end{array}$ & Sangat Tidak Baik \\
\hline 2 & Menganalisis & $\begin{array}{l}7.10- \\
10.00\end{array}$ & Tidak Baik & Melakukan & $\begin{array}{l}14.76- \\
20.50\end{array}$ & Tidak Baik \\
\hline 3 & percobaan & $\begin{array}{l}10.10- \\
13.00\end{array}$ & Baik & percobaan & $\begin{array}{l}20.51- \\
26.25\end{array}$ & Baik \\
\hline 4 & & $\begin{array}{c}13.10- \\
16.00 \\
\end{array}$ & Sangat Baik & & $\begin{array}{l}26.26- \\
32.00 \\
\end{array}$ & Sangat Baik \\
\hline
\end{tabular}

\section{HASIL DAN PEMBAHASAN}

Hasil penelitian ini dirinci secara deskriptif berdasarkan kategori masing-masing indikator keterampilan proses sains. Hasil dari 2 Indikator keterampilan proses sains dasar mahasiswa dapat dilihat pada Tabel 3. 
Tabel 3. Deskripsi Keterampilan Proses Sains Dasar pada Indikator Observasi dan Mengukur.

\begin{tabular}{|c|c|c|c|c|c|c|c|}
\hline \multicolumn{3}{|c|}{ Klasifikasi } & \multirow[b]{2}{*}{$\%$} & \multirow[b]{2}{*}{ Mean } & \multirow[b]{2}{*}{ Median } & \multirow[b]{2}{*}{ Min } & \multirow[b]{2}{*}{ Max } \\
\hline Indikator & $\begin{array}{c}\text { skor } \\
\text { interval }\end{array}$ & kategori & & & & & \\
\hline \multirow{4}{*}{ Observasi } & $5.00-8.75$ & Sangat Tidak Baik & 12.5 & \multirow{4}{*}{14.37} & \multirow{4}{*}{16.00} & \multirow{4}{*}{5.00} & \multirow{4}{*}{20.00} \\
\hline & $\begin{array}{l}8.76- \\
12.50\end{array}$ & Tidak Baik & 17.5 & & & & \\
\hline & $\begin{array}{l}12.51- \\
16.25\end{array}$ & Baik & 32.5 & & & & \\
\hline & $\begin{array}{l}16.26- \\
20.00\end{array}$ & Sangat Baik & 37.5 & & & & \\
\hline \multicolumn{3}{|c|}{ Total } & 100.0 & & & & \\
\hline \multirow{4}{*}{ Mengukur } & $1.00-1.75$ & $\begin{array}{l}\text { Sangat Tidak } \\
\text { Baik }\end{array}$ & 10.0 & \multirow{4}{*}{3.02} & \multirow{4}{*}{3.00} & \multirow{4}{*}{1.00} & \multirow{4}{*}{4.00} \\
\hline & $1.76-2.50$ & Tidak Baik & 17.50 & & & & \\
\hline & $2.51-3.25$ & Baik & 32.5 & & & & \\
\hline & $3.26-4.00$ & Sangat Baik & 40.0 & & & & \\
\hline \multicolumn{3}{|c|}{ Total } & 100.0 & & & & \\
\hline
\end{tabular}

Tabel 3 menunjukkan bahwa untuk indikator melakukan observasi dan indikator mengukur termasuk dalam kategori sangat baik dengan persentasi masing-masing $37.5 \%$ dan $40.0 \%$. Terdapat 2 indikator keterampilan proses sains terpadu yang digunakan pada penelitian ini. Hasil dari 2 Indikator keterampilan proses sains terpadu mahasiswa dapat dilihat pada Tabel 4.

Tabel 4. Deskripsi Keterampilan Proses Sains Terpadu pada Indikator Menganalisis Percobaan dan Melakukan Percobaan

\begin{tabular}{|c|c|c|c|c|c|c|c|}
\hline \multicolumn{3}{|c|}{ Klasifikasi } & \multirow[b]{2}{*}{$\%$} & \multirow[b]{2}{*}{ Mean } & \multirow[b]{2}{*}{ Median } & \multirow[b]{2}{*}{ Min } & \multirow[b]{2}{*}{ Max } \\
\hline Indikator & $\begin{array}{c}\text { Skor } \\
\text { Interval }\end{array}$ & kategori & & & & & \\
\hline \multirow[b]{2}{*}{$\begin{array}{l}\text { Menganalisis } \\
\text { percobaan }\end{array}$} & $4.00-7.00$ & $\begin{array}{l}\text { Sangat Tidak } \\
\text { Baik }\end{array}$ & 10.0 & \multirow[b]{2}{*}{12.3} & \multirow[b]{2}{*}{12.00} & \multirow[b]{2}{*}{4.00} & \multirow[b]{2}{*}{16.00} \\
\hline & $\begin{array}{c}7.10-10.00 \\
10.10-13.00 \\
13.10-16.00\end{array}$ & $\begin{array}{l}\text { Tidak Baik } \\
\text { Baik } \\
\text { Sangat Baik }\end{array}$ & $\begin{array}{l}15.0 \\
40.0 \\
35.0\end{array}$ & & & & \\
\hline Total & & & 100.0 & & & & \\
\hline \multirow{4}{*}{$\begin{array}{l}\text { Melakukan } \\
\text { Percobaan }\end{array}$} & $9.00-14.75$ & $\begin{array}{c}\text { Sangat Tidak } \\
\text { Baik }\end{array}$ & 12.5 & \multirow{4}{*}{24,75} & \multirow{4}{*}{26,5} & \multirow{4}{*}{9.00} & \multirow{4}{*}{34.00} \\
\hline & $14.76-20.50$ & Tidak Baik & 17.5 & & & & \\
\hline & $\begin{array}{l}20.51- \\
26.25\end{array}$ & Baik & 25.0 & & & & \\
\hline & $26.26-32.00$ & Sangat Baik & 45.0 & & & & \\
\hline Total & & & 100.0 & & & & \\
\hline
\end{tabular}

Tabel 4. menunjukkan bahwa untuk indikator menganalisis percobaan termasuk dalam kategori baik dengan persentasi $40.0 \%$ dan untuk indikator melakukan percobaan termasuk dalam kategori sangat baik dengan persentasi $45.0 \%$.

Hasil penelitain ini menunjukkan bahwa mahasiswa Pendidikan Fisika Universitas Jambi tergolong dalam kategori sangat baik saat melakukan praktikum pada materi 
pembiasan pada prisma dengan menggunakan paduan praktikum berbasis Elektronik Modul. Maison, Darmaji, Astalini, Kurniawan, \& Indrawati (2019), menyatakan bahwa "Process skills are the learning outcomes of these students because science process skills emphasize the learning process, activity, creativity, values and also the attitude of students that will be applied in everyday life". Dalam penelitian ini untuk penilaian keterampilan proses sains dasar menggunakan 2 indikator yaitu melakukan observasi dan melakukan pengukuran sedangkan dalam melakukan penilaian keterampilan proses sains terpadu dengan menggunakan 2 indikator juga yaitu indikator menganalisis percobaan dan melakukan percobaan.

Ketercapaian Indikator keterampilan observasi sebesar 37,5\% dari 96 mahasiswa telah tergolong dalam kategori sangat baik. Hal ini didasarkan pada penggunaan panduan berbasis e-modul. Pada indikator mengamati tampak pada saat mahasiswa mengamati untuk mengumpulkan data tentang pengamatan pembiasan pada prisma. Mahasiswa melakukan pengamatan untuk menemukan fakta yang terkait dengan materi praktikum. Sebagai contoh mahasiswa mengamati alat dan bahan yang digunakan dalam percobaan, mahasiswa mengamati jalan sinar pada prisma, mahasiswa mengamati sudut sinar datang dan sudut sinar bias pada prisma. Sahnaz, Harlita, \& Ramli (2018), menyatakan bahwa "Observing skills are skills in identifying differences and similarities in an object”. Kegiatan oberservasi bermanfaat untuk pemenuhan rasa ingin tahu. Proses pengamatan mahasiswa ditunjukkan oleh kemampuan membuat tabel untuk menggambarkan hasil dan mejelaskan dalam grafik. Penguasaan keterampilan observasi memiliki dampak yang baik bagi mahasiswa, dimana mahasiswa dapat menghubungkan pengalaman langsung dengan teori yang mahasiswa ketahui. Hal ini sejalan dengan penelitian yang telah dilakukan Nasih et al (2019), bahwa penggunaan e-modul dapat meningkatkan keterampilan proses sains mahasiswa.

Ketercapaian indikator keterampilan melakukan pengukuran sebesar 40,0\% dari 96 mahasiswa telah tergolong dalam kategori sangat. Indikator pengukuran dalam percobaan pembiasan pada prisma dapat dilihat ketika mahasiswa mampu mengukur sudut sinar datang 1 dengan sudut sinar bias $1\left(i_{1}\right.$ dan $\left.r_{1}\right)$ dan sudut sinar datang 2 dengan sudut sinar bias $2\left(i_{2}\right.$ dan $\left.r_{2}\right)$ menggunakan busur untuk $\left(i_{1} \geq 45^{\circ}\right)$ dengan prosedur yang terampil dan tepat, ini membuktikan bahwa keterampilan mahasiswa diukur ketika mahasiswa mampu mengukur objek sesuai standar pengukuran.

Keterampilan proses sains terpadu yaitu menganalisis percobaan dan melakukan percobaan. Kemampuan observasi merupakan keterampilan yang paling mendasar yang mendukung penguasaan keterampilan berikutnya. Ketika siswa melakukan pengamatan dan menganalisis hasil observasi, maka siswa akan menemukan pola yang dapat 
memprediksi keadaan yang belum terjadi atau diamati (Siska et al., 2013). Pada indikator keterampilan menganalisis percobaan, sebesar 40,0\% dari 96 mahasiswa telah tergolong dalam kategori baik dalam melakukan analisis percobaan. Pada indikator menaganalisis percobaan dalam percobaan pembiasan pada prisma dapat dilihat ketika mahasiswa mampu menganalisis kegunaan alat yang digunakan dalam percobaan pembiasan pada prisma. Pada indikator keterampilan melakukan percobaan, sebesar 45,0\% dari 96 mahasiswa telah tergolong dalam kategori sangat baik dalam melakukan percobaani Pada indikator melakukan percobaan pada praktikum pembiasan pada prisma dapat dilihat ketika mahasiswa mampu menyiapkan alat sesuai tujuan percobaan, mahasiswa mampu meletakan prisma diatas kertas grafik, mahasiswa mampu menancapkan jarum dengan sudut $i \pm 45^{\circ}, i \leq 45^{\circ}, i \geq 45^{\circ}$ dari garis normal, mahasiswa mampu menancapkan jarum $Q$ segaris jarum $P$ ditinjau dari garis seberang prisma, mahasiswa mampu menancapkan jarum $R$ dan $S$ segaris jarum $P$ dan $Q$ pada sisi kanan prisma, mahasiswa mampu menghubungkan titik dari $Q, P, R, S$, mahasiswa mampu memperpanjang garis $P Q$ dan $R S$ dengan semu, mahasiswa mampu menentukan sudut deviasi $(D)$ dan mahasiswa mampu menentukan sinar $\left(i_{1}, i_{2}\right)$ datang, sinar bias $\left(r_{1}, r_{2}\right)$.

Penelitian yang telah dilakukan menunjukkan hasil yang sangat baik karena hal tersebut di dukung oleh penggunaan pedoman praktikum berupa e-modul. Hal ini sejalan dengan penelitian yang telah dilakukan Darmaji, Kurniawan, Astalini, Lumbantoruan, \& Samosir (2019) e-module dapat meningkatkan kemampuan proses sains pada mahasiswa. Dengan menggunakan e-modul mahasiswa mampu melakukan kegiatan laboratorium secara mandiri, mahasiswa dapat membuat data percobaan dengan hasil praktis yang bagus. Mahasiswa menuliskan hasil pengukuran di tabel sesuai dengan data eksperimen yang diperoleh saat praktikum, mahasiswa mampu membuat tabel pengulangan pengukuran berdasarkan jumlah percobaan dilakukan, dan mahasiswa dapat menentukan label/judul tabel yang sesuai dengan masing-masing kolom percobaan. mahasiswa terampil dalam mengobservasi,mengukur menganalisis percobaan dan melakukan percobaan. Sikap ilmiah yang dimiliki oleh mahasiswa sangat berpengaruh pada kegiatan Praktikum hal ini dapat membantu mahasiswa dalam memperoleh pengetahuan secara mandiri disini tidak hanya kemampuan kognitif yang di utamakan tetapi juga kemampuan psikomotor dan afektif (Darmaji, Dwi Agus Kurniawan, Astalini, Wawan Kurniawan, Khairul Anwar, 2019).

Penggunaan mobile learning pada praktikum berbasis buku pedoman praktikum diharapkan untuk memberikan pengalaman baru bagi mahasiswa pendidikan fisika. Shafila Sahnaz, Harlita, (2018), menyatakan bahwa Penggunaan e-modul bisa meningkatkan komunikasi antara mahasiswa dan instruktur praktikum, mahasiswa dapat memperoleh 
sumber belajar, materi belajar dan memperoleh pengalaman pembelajaran yang baru. Media ini menyediakan berbagai fitur yang dapat membantu pengguna untuk mendapatkan bahan ajar dengan cepat dan mudah serta menyediakan instrumen penilaian yang efektif karena e-modul dapat diakses oleh siapa saja, kapan saja dan dimana saja tetapi tetap memperhatikan untuk aspek keterampilan proses sains (Nasih et al., 2019).

\section{SIMPULAN}

Simpulan penelitian ini adalah pengunaan e-modul dapat meningkatkan keterampilan proses mahasiswa dalam melaksanakan kegiatan praktikum dan e-modul sangat membantu tenaga pendidik dalam menciptakan keterampilan proses sains peserta didik. E-modul yang dikembangkan terdapat berbagai kegiatan sains yag dapat dikerjakan peserta didik secara individual.

\section{DAFTAR PUSTAKA}

Asrial, Syahrial, Kurniawan, D. A., Perdana, R., \& Nugroho, P. 2019. Supporting Technology 4.0: Ethoconstructivist Multimedia For Elementary Schools. International Journal Of Online And Biomedical Engineering, 15(14), 54-66. Https://Doi.Org/10.3991/ljoe.V15i14.11365

Astalini, Darmaji, Kurniawan, W., Anwar, K., \& Kurniawan, D. A. 2019. Effectiveness of Using E-Module And E-Assessment. International Journal of Interactive Mobile Technologies, 13(9), 21-39. Https://Doi.Org/10.3991/ljim.V13i09.11016

Astalini, Kurniawan, D. A., Darmaji, Sholihah, L. R., \& Perdana, R. 2019. Characteristics of Students' Attitude to Physics In Muaro Jambi High School. Humanities And Social Sciences Reviews, 7(2), 91-99. Https://Doi.Org/10.18510/Hssr.2019.7210

Astuti, S. P. 2015. Pengaruh Kemampuan Awal Dan Minat Belajar Terhadap Prestasi Belajar Fisika. Formatif: Jurnal Ilmiah Pendidikan Mipa, 5(1), 68-75. Https://Doi.Org/10.30998/Formatif.V5i1.167

Aydın, A. (2013). Representation of Science Process Skills in the Curricula for Grades 10, 11 and 12/Turkey. International Journal of Education and Practice, 1(5), 51-63.

Azizoğlu*, F. D. And N. 2010. Investigation Of The Students ' Science Process Skill Levels In Vocational Schools: A Case of Bal I Kesir. Necatibey Faculty Of Education Electronic Journal Of Science And Mathematics Education, 4(2), 79-109.

Cahyani, H., \& Setyawati, R. W. 2016. Pentingnya Peningkatan Kemampuan Pemecahan Masalah Melalui PBL untuk Mempersiapkan Generasi Unggul Menghadapi MEA. Prisma, Prosiding Seminar Nasional Matematika, 151-160.

Dari, R. W., \& Nasih, N. R. 2019. Identifikasi Tingkat Kps Mahasiswa Praktikum Pembiasan Kaca Plan Paralel Menggunakan Panduan Praktikum Berbasis E-Modul. Jifp (Jurnal IImu Fisika Dan Pembelajarannya), 3(2), 47-57. 
Darmaji, Dwi Agus Kurniawan, Astalini, Wawan Kurniawan, Khairul Anwar, A. L. 2019. Students' Perceptions Of Electronic's Module In Physics Practicum. Journal Of Education And Learning (Edulearn), 13(2), 288-294. Https://Doi.Org/10.11591/Edulearn.V13i2.13005

Darmaji, Dwi Agus Kurniawan, Hanaiyah Parasdila, I. 2018. Description of Science Process Skills' Physics Education Students at Jambi University In Temperature And Heat Materials. Educational Review, Usa, 2(9), 485-498. Https://Doi.Org/10.26855/Er.2018.09.004

Darmaji, Astalini, Kurniawan, D. A., Parasdila, H., Irdianti, Hadijah, S., \& Perdana, R. 2019. Practicum Guide: Basic Physics Based of Science Process Skill. Humanities and Social Sciences Reviews, 7(4), 151-160. Https://Doi.Org/10.18510/Hssr.2019.7420

Darmaji, Kurniawan, D. A., Astalini, Lumbantoruan, A., \& Samosir, S. C. 2019. Mobile Learning In Higher Education For The Industrial Revolution 4.0: Perception And Response of Physics Practicum. International Journal of Interactive Mobile Technologies, 13(9), 4-20. Https://Doi.Org/10.3991/ljim.V13i09.10948

Gultepe, N. 2016. High School Science Teachers' Views on Science Process Skills. International Journal of Environmental And Science Education, 11(5), 779-800. Https://Doi.Org/10.12973/ljese.2016.348a

Hırça, N. 2012. The Influence of Hands on Physics Experiments on Scientific Process Skills According to Prospective Teachers' Experiences. European J of Physics Education, 4(1), 1-9. Retrieved From Http://Ejpe.Erciyes.Edu.Tr/Index.Php/Ejpe/Article/View/82

Karamustafaoğlu, S. 2011. Improving The Science Process Skills Ability of Science Student Teachers Using I Diagrams. Eurasian J. Phys. Chem. Educ, 3(1), 26-38. Retrieved From Http://Www.Eurasianjournals.Com/Index.Php/Ejpce

Kunlestiowati, H., Yuningsih, N., Martono, W., \& Politeknik, N. B. 2016. Penentuan Sudut Deviasi Minimum Prisma Melalui Peristiwa Pembiasan Cahaya Berbantuan Komputer Determination of Minimum Deviation Angle of Prism Through The Light Refraction Assisted By A Computer. 8, 1-6.

Maison, Astalini, Dwi Agus Kurniawan, L. R. S. 2018. Maison, Astalini, Dwi Agus Kurniawan, Lintang Rofiatus Sholihah. 10(1), 160-167.

Maison, Darmaji, Astalini, Kurniawan, D. A., \& Indrawati, P. S. 2019. Science Process Skills and Motivation. Humanities and Social Sciences Reviews, 7(5), 48-56. Https://Doi.Org/10.18510/Hssr.2019.756

Maison, Syahrial, Syamsurizal, \& Tanti. 2012. Learning Environment, Students' Beliefs, and Self-Regulation In Learning Physics: Structural Equation Modeling. 18(3), 389403. Https://Doi.Org///Doi.Org/10.33225/Jbse/19.18.389

Nasih, N. R., Sinaga, S., Studi, P., Fisika, P., Jambi, U., Studi, P., ... Sains, K. P. 2019. Hubungan Persepsi Mahasiswa Pada E-Module Materi. 4(2).

Nasir, M., Fakhrunnisa, R., \& Nastiti, L. R. (2019). The Implementation of Project-Based Learning and Guided Inquiry to Improve Science Process Skills and Student Cognitive Learning Outcomes. International Journal of Environmental and Science Education, 14(5), 229-238. 
Nugraha, M. G., Utari, S., Saepuzaman, D., Solihat, F. N., \& Kirana, K. H. 2019. Development of Basic Physics Experiments Based on Science Process Skills (Sps) To Enhance Mastery Concepts of Physics Pre-Service Teachers in Melde's Law. Journal of Physics: Conference Series, 1280(5). Https://Doi.Org/10.1088/1742$6596 / 1280 / 5 / 052075$

Putri, A. R., Maison, M., \& Darmaji, D. 2018. Kerjasama dan Kekompakan Siswa Dalam Pembelajaran Fisika Di Kelas Xi Mipa Sma Negeri 3 Kota Jambi. Edufisika, 3(02), 3240. Https://Doi.Org/10.22437/Edufisika.V3i02.5552

Remziye Ergul, Simsekli, Y., Calis, S., Ozdilek, Z., Gocmencelebi, S., \& Sanli, M. 2011. The Effects of Inquiry-Based Science Teaching on Elementary School Students' Science Process Skills And Science Attitudes. Bulgarian Journal of Science And Education Policy (Bjsep), 5(1), 48-69.

Sahnaz, S., Harlita, H., \& Ramli, M. 2018. Improving Observing Skills of High School Students Through Guided Inquiry Model. International Journal of Pedagogy And Teacher Education, 2(1), 53. Https://Doi.Org/10.20961/ljpte.V2i1.16608

Shafila Sahnaz, Harlita Harlita, M. R. 2018. Improving Observing Skills Of High School Students Through Guided Inquiry Mode. International Journal Of Pedagogy And Teacher Education, 2(1), 47-57.

Suarsana, I. M., \& Mahayukti, G. A. 2013. Pengembangan E-Modul Berorientasi Pemecahan Masalah Untuk Meningkatkan Keterampilan Berpikir Kritis Mahasiswa. Jurnal Nasional Pendidikan Teknik Informatika (Janapati), 2(3), 193. Https://Doi.Org/10.23887/Janapati.V2i3.9800

Wahyuni, S., Indrawati, I., Sudarti, S., \& Suana, W. 2017. Developing Science Process Skills And Problem-Solving Abilities Based on Outdoor Learning In Junior High School. Jurnal Pendidikan Ipa Indonesia, 6(1), 165-169. Https://Doi.Org/10.15294/Jpii.V6i1.6849

Willingham, D. T. 2008. Critical Thinking: Why Is It So Hard To Teach? Arts Education Policy Review, 109(4), 21-32. Https://Doi.Org/10.3200/Aepr.109.4.21-32 